\title{
Validation of Simultaneous Endoscopic Sinus Surgery and Transsphenoidal Surgery in Patients with Chronic Rhinosinusitis and Pituitary Tumors
}

\author{
Sung Yool Park, Seong Kook Park ${ }^{\mathbb{D}}$, Donghoo Lee, Do Hun Kim ${ }^{\mathbb{D}}$, \\ Woo Jin Kim, Chanhyeon Park, Junhyuk Jang, and Kyung Wook Heo \\ Department of Otorhinolaryngology-Head and Neck Surgery, Inje University Busan Paik Hospital, Busan, Korea \\ 만성 부비동염과 뇌하수체 종양을 가진 환자에서 동시에 시행된 비내시경수술과 경접형동 접근법 \\ 박성율 · 박성국 · 이동후 · 김도훈 · 김우진 · 박찬현 · 장준혁 · 허경욱 \\ 인제대학교 부산백병원 이비인후-두경부외과
}

Received January 17, 2020

Revised April 20,2020

Accepted April 24, 2020

Address for correspondence

Kyung Wook Heo, MD, PhD

Department of Otorhinolaryngology-

Head and Neck Surgery,

Inje University Busan Paik Hospital,

75 Bokji-ro, Busanjin-gu,

Busan 47392, Korea

Tel $+82-51-890-6375$

Fax $+82-51-892-3831$

E-mail heokw96@daum.net
Background and Objectives Transsphenoidal (TS) surgery for removal of pituitary lesions has become popular with improvements in diagnostic and treatment modalities, as well as endonasal and endoscopic methods, resulting in reduced complications. Rhinosinusitis (RS) is considered a risk factor for postoperative intracranial infections. Previously, we showed that concurrent TS surgery and endoscopic sinus surgery (ESS) yielded a favorable outcome in cases with pituitary lesions and RS. However, there seems to be a lack of consensus in performing simultaneous TS and ESS for patients with a pituitary lesion and RS. We would like to validate the feasibility of performing two operations concurrently.

Subjects and Method We reviewed the medical records of 13 patients who underwent simultaneous TS surgery and ESS between 2007 and 2016. One patient underwent concurrent TS surgery and ESS twice due to the regrowth of pituitary macroadenoma and recurrence of RS.

Results There were only four minor nasal complications during the postoperative period, which were controlled with conservative treatment. Only one patient exhibited postoperative cerebrospinal fluid leakage and no patients experienced intracranial complications.

Conclusion This study shows that it might be better to treat patients with pituitary lesion and RS simultaneously. Also, further studies with large cases would be necessary to manage these patients without intracranial complications.

Korean J Otorhinolaryngol-Head Neck Surg 2020;63(11):505-10

Key Words Endoscopy $\cdot$ Hypophysectomy $\cdot$ Pituitary neoplasms $\cdot$ Sinusitis.

\section{Introduction}

Transsphenoidal (TS) surgery for removal of pituitary lesions has been performed since the early part of the 20th century, and became popular due to the introduction of improved diagnostic and treatment modalities such as CT, MRI, antibiotics,

This is an Open Access article distributed under the terms of the Creative Commons Attribution Non-Commercial License (https://creativecommons.org/licenses/by-nc/4.0) which permits unrestricted non-commercial use, distribution, and reproduction in any medium, provided the original work is properly cited. operative microscopes, and surgical endoscopes. ${ }^{2)}$ Accordingly, the complications of TS surgery have decreased dramatically. ${ }^{3,4)}$

The prevalence of rhinosinusitis (RS) in adults is approximately $12 \%$ in the United States. ${ }^{5)}$ Bacterial acute RS is associated with potential complications including orbital infection, meningitis, and brain abscess. ${ }^{6,7)}$ Prior to the introduction of TS surgery for removal of pituitary lesions, pre-existing RS was considered a risk factor for postoperative intracranial infections, such as meningitis; moreover, TS surgery was considered to be 
contraindicated in patients with $\mathrm{RS}^{8)}$ Thus, controlling RS before performing TS surgery was strongly recommended, but the delay to surgery resulted in further deterioration of neurologic condition, manifested in vision changes, headache, and abnormal endocrine function. ${ }^{3,9)}$

We previously reported the operative outcomes of concurrent treatment of pituitary adenoma and chronic RS; the work was preliminary in nature. Postoperatively, no increase in the extent of RS was seen. ${ }^{2)}$ However, there seems no consensus to perform simultaneous TS and sinus surgery for patients with pituitary lesion and RS. In the present study, we evaluated a consecutive series of patients who underwent surgery for chronic RS and pituitary lesions simultaneously, to validate the feasibility of performing the two operations concurrently as the previous report. ${ }^{2)}$

\section{Subjects and Method}

\section{Patients and preoperative evaluation}

Between November 2007 and December 2016, 149 patients (71 men and 78 women) underwent 158 TS surgeries due to pituitary lesions at a tertiary referral center. The mean age of the patients was 47.1 years (range: 16-78 years).

The indications for TS surgery were pituitary adenomas causing visual field defects, acromegaly, or treatment-refractory amenorrhea. RS was diagnosed, in accordance with the clinical practice guidelines of the American Academy of Otolaryngology-Head and Neck Surgery, ${ }^{10)}$ by the presence of at least two out of four cardinal symptoms (i.e., facial pain/pressure, hyposmia/anosmia, nasal drainage, and nasal obstruction) for at least 12 consecutive weeks. Objective evidence of chronic RS was obtained on physical examination (e.g., mucopurulent drainage, edema, polyps in the middle meatus) and radiology of paranasal sinus (PNS) if needed.

When the TS surgery is scheduled as the surgical treatment, all patients are sent to otolaryngologist before proceeding with the TS for preoperative evaluation, mainly to check for possible nose and PNS lesion. Also, preoperative work-up included comprehensive neurologic, ophthalmologic, and endocrinologic evaluations. After history taking focused at above mentioned symptoms, all of them were evaluated by nasal endoscopy. If there were mucoid discharge from middle or superior meatus and/or diffuse mucosal swelling of the nasal cavity, subjects were treated with oral cefuroxime axetil or cefixime for 2 weeks. Then, all patients were re-evaluated on the base of symptoms, nasal endoscopy, and PNS CT scans. If RS per- sisted, they received concurrent TS surgery and endoscopic sinus surgery (ESS). The diagnosis and treatment strategy process is summarized in Fig. 1.

Sellar MRI were checked before and after surgery in nearly all patients; pre- and postoperative (at the 8th week after operation) Lund-Mackay scores were recorded. Medical records were reviewed regarding the perioperative course, as were intraoperative findings and images. Postoperative nasal endoscopy findings, any medical notes, and imaging results were checked and analyzed. This study was approved by the Local Ethics Committee of our hospital (IRB No. 19-0026).

\section{Surgical procedure}

After general anesthesia was induced via orotracheal intubation, ESS was first performed according to the extent of the sinus lesion to avoid potential effect from sinus lesion. Prior to the introduction of endoscopic TS surgery, the first three patients underwent TS surgery using the transcolumellar endoscope-assisted transseptal approach; the remaining patients underwent TS surgery via the transnasal endoscopic approach, as described previously. ${ }^{2)}$

Postoperatively, patients were administered intravenous antibiotics (ceftriaxone, $4 \mathrm{~g}$ /day) with neurosurgical drugs

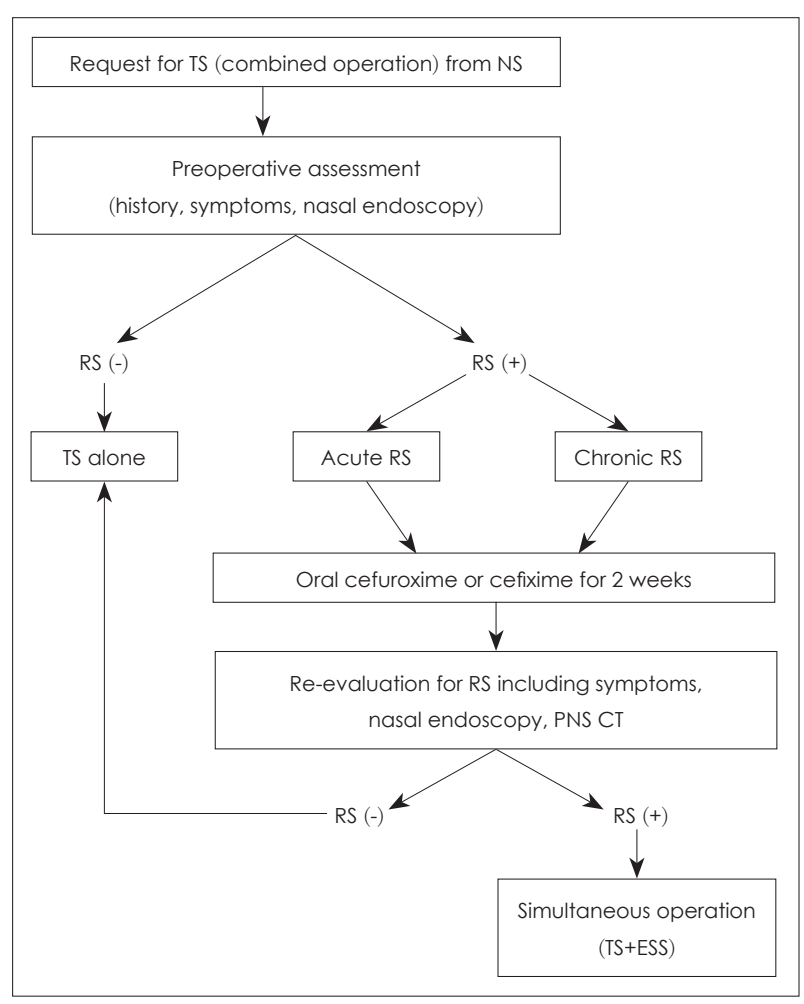

Fig. 1. Diagnosis and treatment flow for patients scheduled for TS. TS: transsphenoidal surgery, NS: neurosurgery, RS: rhinosinusitis, PNS: paranasal sinus, ESS: endoscopic sinus surgery. 
for one week, and then discharged from the department of neurosurgery and prescribed oral cefdinir (300 mg/day) for three weeks, and then low-dose roxithromycin (150 mg/day) for the three months. Regular follow-up at outpatient clinic $(1,2,4,8$, and 12 weeks after discharge) was performed with dressing under angled endoscopy \& post-operative PNS CT scans at 8 th week.

\section{Results}

During the study period, $13(8.7 \%)$ of 149 patients who underwent TS surgery ( 9 men and 4 women; mean age, 49.2 years) underwent concurrent TS surgery and ESS for pituitary lesions and RS (Table 1). None of the patients had previously undergone nasal surgery.

Preoperatively, all patients had chronic RS, and their mean \pm standard deviation Lund-Mackay score was $9.1 \pm 4.1$ (range: 4-16). Three types of pituitary pathology were seen: ten macroadenomas (including case No. 8, which was producing growth hormone), two microadenomas producing prolactin (cases No. 2 and 9), and one cyst. Patient No. 6 was a man who had undergone TS surgery before the study began and underwent concurrent TS revision surgery and ESS due to regrowth of pituitary macroadenoma and new-onset chronic RS. Patient No. 7 underwent simultaneous TS surgery and ESS twice (operation Nos. 7 and 8; interval of 78 months) due to regrowth of pituitary macroadenoma and re- current chronic RS (Fig. 2).

Postoperatively, four patients had temporary nasal complications (synechia, $\mathrm{n}=2$; nasal crusting, $\mathrm{n}=1$; and $\mathrm{RS}, \mathrm{n}=1$ ), which were controlled by conservative methods such as medication, saline irrigation, and ointment application. In patient No. 7, after operation No. O8, cerebrospinal fluid (CSF) leakage from the sellar floor was seen on postoperative day 5. Packing with TachoSil ${ }^{\circledR}$ (Hyundai Pharm, Seoul, Korea) was sufficient to control the leakage. The mean \pm standard deviation postoperative Lund-Mackay score 6 months postoperatively was $2.2 \pm 1.7$ (range: $1-7$ ). No patients exhibited postoperative intracranial infection.

\section{Discussion}

When pituitary lesions become symptomatic, surgery is the first line treatment method; endoscopic TS surgery is becoming more popular than traditional transcranial and microscopic techniques. ${ }^{8)}$ Two major drawbacks of TS surgery are visual field restriction during surgery, especially around the optic nerves, and the risk of cranial complications, such as meningitis and CSF leakage. ${ }^{11)}$ While visual field restriction during surgery was resolved by the introduction of surgical endoscopy and navigation systems, the risk of cranial complications has remained a challenge for surgeons. ${ }^{12)} \mathrm{Cur}-$ rently, the endonasal endoscopic approach is frequently used to treat pituitary lesions; it is gradually becoming the pre-

Table 1. Patient demographic characteristics, symptoms, perioperative Lund-Mackay scores, pituitary pathologies, and complications

\begin{tabular}{|c|c|c|c|c|c|c|c|c|c|}
\hline $\begin{array}{c}\text { Case } \\
\text { no. }\end{array}$ & $\begin{array}{l}\text { OP } \\
\text { no. }\end{array}$ & $\begin{array}{c}\text { Sex/age } \\
(y r)\end{array}$ & $\begin{array}{l}\text { Pre nasal } \\
\text { symptoms }\end{array}$ & $\begin{array}{l}\text { Pre LM } \\
\text { score }\end{array}$ & Involved sinus & $\begin{array}{l}\text { Pituitary } \\
\text { pathology }\end{array}$ & $\begin{array}{c}\text { Nasal Cx for } \\
3 \mathrm{mo}\end{array}$ & $\begin{array}{c}\text { Cranial } \mathrm{Cx} \text { for } \\
3 \mathrm{mo}\end{array}$ & $\begin{array}{c}\text { Post LM } \\
\text { score }\end{array}$ \\
\hline 1 & 01 & $M / 67$ & $\mathrm{PD}, \mathrm{HN}$ & 4 & $\mathrm{AE}(\mathrm{L}) \mathrm{PE}(\mathrm{L}) \mathrm{M}(\mathrm{L})$ & Ma & Synechia & None & 2 \\
\hline 2 & O2 & $\mathrm{F} / 55$ & $\mathrm{FP}, \mathrm{HN}$ & 5 & $A E(B) P E(B)$ & Ma & None & None & 0 \\
\hline 3 & O3 & $F / 65$ & $\mathrm{NO}, \mathrm{AN}$ & 5 & $\mathrm{AE}(\mathrm{L}) \mathrm{PE}(\mathrm{L}) \mathrm{M}(\mathrm{L})$ & Ma & Synechia & None & 2 \\
\hline 4 & $\bigcirc 4$ & $M / 44$ & $M R, N O$ & 8 & $\mathrm{AE}(\mathrm{B}) \mathrm{PE}(\mathrm{B}) \mathrm{MI}(\mathrm{B})$ & Ma & None & None & 2 \\
\hline 5 & O5 & $F / 27$ & $\mathrm{MR}, \mathrm{NO}, \mathrm{HN}$ & 12 & $\mathrm{AE}(\mathrm{B}) \mathrm{PE}(\mathrm{B}) \mathrm{MI}(\mathrm{B}) \mathrm{M}(\mathrm{L})$ & Cyst & None & None & 3 \\
\hline 6 & O6 & $M / 51$ & $\mathrm{NO}, \mathrm{PD}, \mathrm{AN}$ & 11 & $\mathrm{~F}(\mathrm{~B}) \mathrm{AE}(\mathrm{B}) \mathrm{S}(\mathrm{B}) \mathrm{Ml}(\mathrm{R})$ & Ma & None & None & 3 \\
\hline 7 & O7 & $F / 63$ & $\mathrm{FO}, \mathrm{MR}, \mathrm{PD}$ & 11 & $\mathrm{AE}(\mathrm{B}) \mathrm{PE}(\mathrm{B}) \mathrm{MI}(\mathrm{B}) \mathrm{M}(\mathrm{L})$ & Ma & None & None & 3 \\
\hline 7 & O8 & $F / 63$ & $F O, M R, F P$ & 16 & $\mathrm{AE}(\mathrm{B}) \mathrm{PE}(\mathrm{B}) \mathrm{Ml}(\mathrm{B}) \mathrm{M}(\mathrm{B})$ & Ma & None & CSF leakage* & 0 \\
\hline 8 & O9 & $M / 45$ & $\mathrm{NO}, \mathrm{SN}, \mathrm{MR}$ & 13 & $\mathrm{AE}(\mathrm{B}) \mathrm{PE}(\mathrm{B}) \mathrm{Ml}(\mathrm{B}) \mathrm{M}(\mathrm{B})$ & Ma & None & None & 2 \\
\hline 9 & 010 & $M / 29$ & $\mathrm{NO}, \mathrm{FP}$ & 9 & $\mathrm{~F}(\mathrm{~L}) \mathrm{AE}(\mathrm{B}) \mathrm{MI}(\mathrm{B})$ & Ma & None & None & 3 \\
\hline 10 & 011 & $M / 38$ & $M R, N O$ & 6 & $\mathrm{AE}(\mathrm{B}) \mathrm{PE}(\mathrm{B}) \mathrm{MI}(\mathrm{R})$ & $\mathrm{Ma}$ & None & None & 1 \\
\hline 11 & 012 & $M / 42$ & $M R, F P$ & 7 & $\mathrm{AE}(\mathrm{B}) \mathrm{PE}(\mathrm{B}) \mathrm{MI}(\mathrm{L})$ & Ma & None & None & 2 \\
\hline 12 & 013 & $M / 65$ & $\mathrm{NO}, \mathrm{AN}$ & 5 & $\mathrm{AE}(\mathrm{B}) \mathrm{MI}(\mathrm{B})$ & Ma & Crusting & None & 1 \\
\hline 13 & 014 & $M / 49$ & $\mathrm{NO}, \mathrm{HN}, \mathrm{SN}$ & 16 & $\mathrm{~F}(\mathrm{~B}) \mathrm{AE}(\mathrm{B}) \mathrm{PE}(\mathrm{B}) \mathrm{MI}(\mathrm{B}) \mathrm{M}(\mathrm{B})$ & Ma & Rhinosinusitis & None & 7 \\
\hline
\end{tabular}

*CSF leakage was controlled mainly by TachoSil ${ }^{\circledR}$ (Hyundai Pharm, Seoul, Korea). Op: operation, no.: number, y: years, mo: months, Pre: preoperative, LM: Lund-Mackay, Cx: complication, Post: postoperative, PD: postnasal drip, HN: hyposmia, FP: facial pain, NO: nasal obstruction, AN: anosmia, MR: mucoid rhinorrhea, FO: foul odor, SN: snoring, AE: anterior ethmoid, PE: posterior ethmoid, M: maxillary, Ml: middle meatus, F: frontal, S: sphenoid, Ma: macroadenoma, CSF: cerebrospinal fluid 

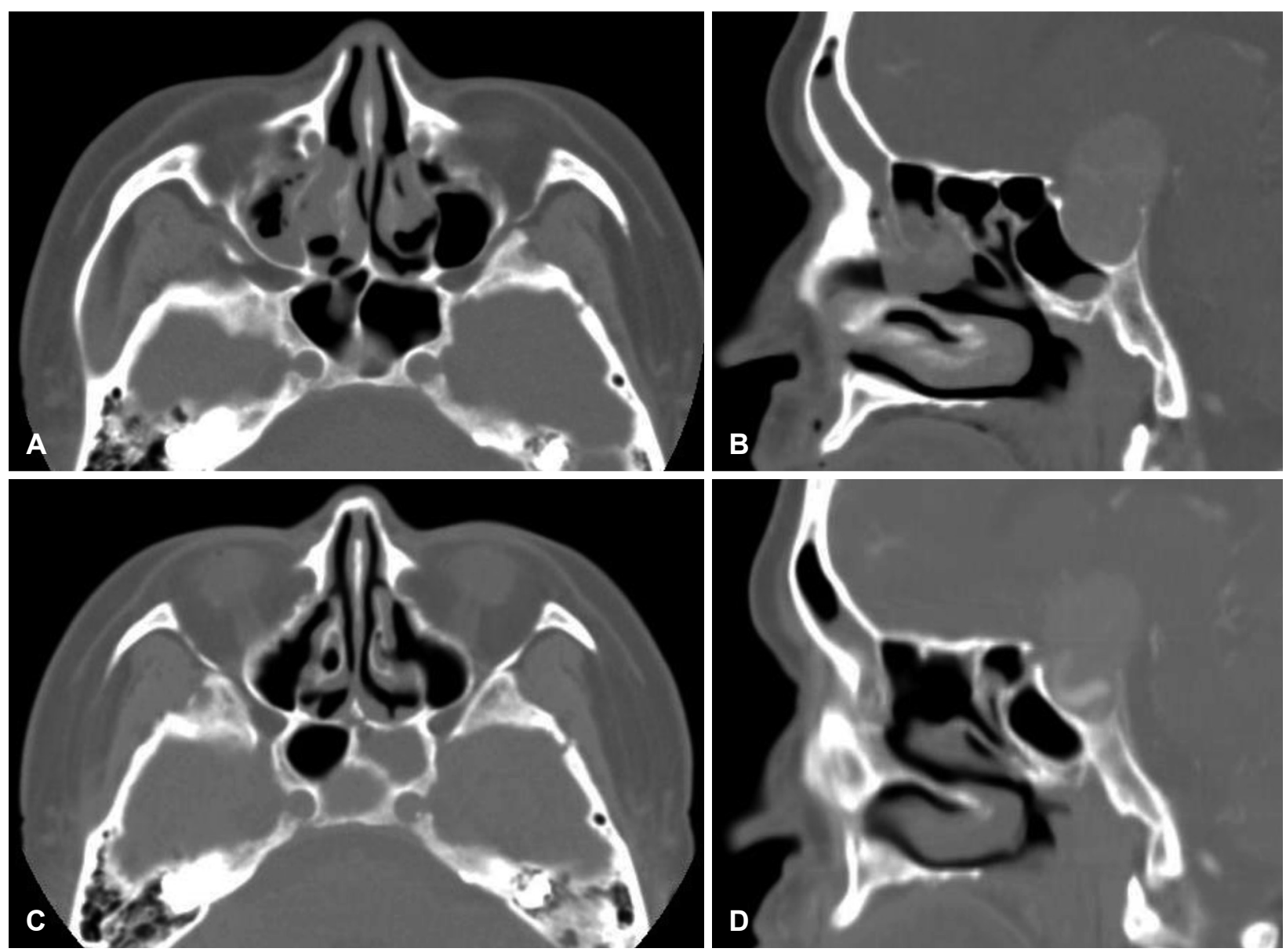

Fig. 2. Perioperative PNS CT in patient No. 6 (51-year-old man). Preoperatively, there was diffuse haziness in the right middle meatus and both anterior ethmoid sinuses, also with near total haziness right frontal sinus (A, axial; B, sagittal). Postoperative PNS CT shows a well-aerated right middle meatus and both ethmoidectomized cavities, marked improvement of right frontal sinus haziness, some residual pituitary macroadenoma, with increased haziness apparent in the left sphenoid sinus due to sellar floor reconstruction and packing with autologous tissues (C, axial; D, sagittal). PNS: paranasal sinus.

ferred approach for most pituitary tumors. ${ }^{8)}$

The incidence of meningitis due to TS surgery has been reported to range from $0.4 \%$ to $9 \%{ }^{4,13,14)}$ According to previous studies, meningitis after TS surgery was predominantly caused by Gram-negative bacteria. ${ }^{15,16)}$ However, there was no relationship between pre-TS cultures from nasal swabs and the organisms in the CSF of patients with post-TS meningitis. ${ }^{17,18)}$ van Aken, et al. ${ }^{8)}$ strongly suggested that infection due to CSF leakage developed postoperatively rather than intraoperatively; moreover, in patients with post-TS CSF rhinorrhea, the risk of meningitis was high. ${ }^{17)}$ In our series, no patients had post-TS meningitis. The limited number of cases (13 subjects) due to scarcity of concurrent surgery, of course, seems not enough to conclude that pre-TS RS could be controlled safely by concurrent TS and ESS in this study. However, we believe that our experience in controlling pre-TS RS, accrued since 2004 , leads us to minimize potential adverse effect from intra- and postoperative CSF leakage.

Previous studies described three risk factors for meningitis following TS surgery., ${ }^{4,18-20)}$ Sphenoiditis was recently reported as a risk factor, although several studies have stated that RS is not related to postoperative CNS infection. ${ }^{3,4,20-22)}$ Prophylactic management has been recommended before TS surgery, being classified as a clean-contaminated procedure due to the air-containing sphenoid sinus. ${ }^{23)}$ Schaberg, et al. ${ }^{18)}$ reported that seven patients with preoperative sphenoiditis underwent concurrent ESS and endoscopic surgery of the anterior skull base; no postoperative intracranial complications were noted. Larger case series are needed to determine the risk of intracranial complications due to pre-TS sphenoiditis. Previously, in a case of sphenoiditis, we irrigated the opened sinuses with antibiotic-containing saline, ${ }^{2)}$ an approach that has since been abandoned. No patients had acute RS in our case series, but for patients with acute RS and pituitary le- 
sions requiring TS surgery, several reports have recommended initially controlling the acute RS with antibiotics, topical steroids, nasal irrigation, and antihistamines. ${ }^{18-20,24)}$ Subsequently, concurrent TS surgery with ESS can be performed, with minimal risk of postoperative cranial infection. ${ }^{19,20)}$

CSF leakage has also been reported in association with meningitis after TS surgery. ${ }^{17,25)}$ During TS surgery, CSF leakage occurs in up to $50 \%$ of patients. ${ }^{26)}$ To prevent this, various techniques have been used, including intra-sellar/sphenoidal placement of soft tissues together with intraoperative reconstruction of the sellar floor. ${ }^{26,27)}$ Nasoseptal, dural, and free omental flap techniques have also been used. ${ }^{28,29)}$ However, despite the availability of these procedures, CSF leakage after TS surgery remains an important risk factor for meningitis, especially during the postoperative period. ${ }^{4)}$ We encountered one patient with postoperative CSF leakage who underwent concurrent revision TS surgery and ESS. Various artificial materials can be used to control CSF leakage successfully. ${ }^{30)}$ Recently, Kim, et al. ${ }^{31)}$ reported two out of eight patients with post-TS meningitis who underwent sequential TS after ESS. Of those subjects, five patients had CSF leakage during TS.

Finally, Cushing's disease is considered a risk factor for postTS meningitis due its association with impaired immunity. ${ }^{32}$

In conclusion, we performed simultaneous TS surgery and ESS on 13 patients and observed no intracranial complications, even in those undergoing concurrent revision operations. We believe that the successful outcomes were possible due to improved scientific knowledge and our treatment experience. Our findings might help to determine methods in treating patients with pituitary lesion and RS simultaneously. Also, further studies with large cases would be necessary to manage these patients without intracranial complications.

\section{Acknowledgments}

The authors thank Young Gyun Jeong, MD. for involving us in the management of their patients.

\section{Author Contribution}

Conceptualization: Kyung Wook Heo, Seong Kook Park. Data curation: Kyung Wook Heo, Donghoo Lee. Formal analysis: Kyung Wook Heo, Woo Jin Kim. Investigation: Chanhyeon Park, Junhyuk Jang. Methodology: Kyung Wook Heo. Project administration: Sung Yool Park, Kyung Wook Heo. Validation: Do Hun Kim, Woo Jin Kim. Visualization: Kyung Wook Heo. Writing_-original draft: Sung Yool Park. Writing — review \& editing: Kyung Wook Heo.

\section{ORCIDs}

Kyung Wook Heo

https://orcid.org/0000-0002-4729-0135

Seong Kook Park

https://orcid.org/0000-0003-3903-8412

Do Hun Kim

https://orcid.org/0000-0003-4573-9565

\section{REFERENCES}

1) Topuz MF, Sarı M, Binnetoglu A, Dogrul R, Bugdaycı O, Şeker A. Is endoscopic endonasal transsphenoidal surgery increases the susceptibility to rhinosinusitis. Eur Arch Otorhinolaryngol 2017;274(8):3065-9.

2) Heo KW, Park SK. Rhinologic outcomes of concurrent operation for pituitary adenoma and chronic rhinosinusitis: An early experience. Am J Rhinol 2008;22(5):533-6.

3) Kuan EC, Rereddy SK, Patel NN, Maina IW, Triantafillou V, Kohanski MA, et al. Asymptomatic radiographic sinonasal inflammation does not affect pituitary surgery outcomes. Laryngoscope 2019;129(7):1545-8.

4) Kim DH, Hong YK, Jeun SS, Park JS, Kim SW, Cho JH, et al. Is coincidental rhinosinusitis a predisposing factor for postoperative central nervous system infection after endoscopic endonasal transsphenoidal surgery? J Craniofac Surg 2018;29(3):e319-22.

5) Blackwell DL, Lucas JW, Clarke TC. Summary health statistics for U.S. adults: National health interview survey, 2012. Vital Health Stat 10 2014;(260):1-161.

6) Clayman GL, Adams GL, Paugh DR, Koopmann CF Jr. Intracranial complications of paranasal sinusitis: A combined institutional review. Laryngoscope 1991;101(3):234-9.

7) Hytönen M, Atula T, Pitkäranta A. Complications of acute sinusitis in children. Acta Otolaryngol Suppl 2000;543:154-7.

8) van Aken MO, de Marie S, van der Lely AJ, Singh R, van den Berge $\mathrm{JH}$, Poublon RM, et al. Risk factors for meningitis after transsphenoidal surgery. Clin Infect Dis 1997;25(4):852-6.

9) Bae WY, Kim SH, Kang MY, Koh TK. Efficacy of controlling rhinosinusitis on the prevention of complications in pituitary surgery with transsphenoidal approach. Auris Nasus Larynx 2014;41(1):50-2.

10) Rosenfeld RM, Piccirillo JF, Chandrasekhar SS, Brook I, Kumar KA, Kramper M, et al. Clinical practice guideline (update): Adult sinusitis. Otolaryngol Head Neck Surg 2015;152(2 Suppl):S1-39.

11) Laws ER Jr, Thapar K. Surgical management of pituitary adenomas. Baillieres Clin Endocrinol Metab 1995;9(2):391-405.

12) Wang EW, Zanation AM, Gardner PA, Schwartz TH, Eloy JA, Adappa ND, et al. ICAR: Endoscopic skull-base surgery. Int Forum Allergy Rhinol 2019;9(S3):S145-365.

13) Yu B, Ji N, Ma Y, Yang B, Kang P, Luo F. Clinical characteristics and risk factors for headache associated with non-functioning pituitary adenomas. Cephalalgia 2017;37(4):348-55.

14) Guvenc G, Kizmazoglu C, Pinar E, Imre A, Kaya I, Bezircioglu H, et al. Outcomes and complications of endoscopic versus microscopic transsphenoidal surgery in pituitary adenoma. J Craniofac Surg 2016; 27(4):1015-20.

15) Wilson CB, Dempsey LC. Transsphenoidal microsurgical removal of 250 pituitary adenomas. J Neurosurg 1978;48(1):13-22.

16) Haile-Mariam T, Laws E, Tuazon CU. Gram-negative meningitis associated with transsphenoidal surgery: Case reports and review. Clin Infect Dis 1994;18(4):553-6.

17) Weber RS, Callender DL. Antibiotic prophylaxis in cleancontaminated head and neck oncologic surgery. Ann Otol Rhinol Laryngol Suppl 1992;155:16-20.

18) Schaberg MR, Shah GB, Evans JJ, Rosen MR. Concomitant transsphenoidal approach to the anterior skull base and endoscopic sinus surgery in patients with chronic rhinosinusitis. J Neurol Surg B Skull Base 2013;74(4):241-6.

19) Nyquist GG, Friedel ME, Singhal S, Beahm DD, Farrell CJ, Evans JJ, et al. Surgical management of rhinosinusitis in endoscopicendonasal skull-base surgery. Int Forum Allergy Rhinol 2015;5(4): 339-43.

20) Herman P, Lot G, Guichard JP, Marianowski R, Assayag M, Tran Ba Huy P. Mucocele of the sphenoid sinus: A late complication of transsphenoidal pituitary surgery. Ann Otol Rhinol Laryngol 
1998;107(9 Pt 1):765-8.

21) Antimicrobial prophylaxis in neurosurgery and after head injury. Infection in Neurosurgery Working Party of the British Society for Antimicrobial Chemotherapy. Lancet 1994;344(8936):1547-51.

22) Lubbe D, Semple P. Pre-operative assessment of patients undergoing endoscopic, transnasal, transsphenoidal pituitary surgery. J Laryngol Otol 2008;122(6):644-6.

23) Uren B, Vrodos N, Wormald PJ. Fully endoscopic transsphenoidal resection of pituitary tumors: Technique and results. Am J Rhinol 2007;21(4):510-4.

24) Mehta GU, Oldfield EH. Prevention of intraoperative cerebrospinal fluid leaks by lumbar cerebrospinal fluid drainage during surgery for pituitary macroadenomas. J Neurosurg 2012;116(6):1299-303.

25) Kim BY, Shin JH, Kang SG, Kim SW, Hong YK, Jeun SS, et al. Bilateral modified nasoseptal "rescue" flaps in the endoscopic endonasal transsphenoidal approach. Laryngoscope 2013;123(11): 2605-9.

26) So J, Park H, Sung KS, Lee KS, Hong CK. Sandwich technique using fibrin-coated collagen fleece for sellar reconstruction in large dural defects during transsphenoidal surgery. J Clin Neurosci 2017;43:256-60.
27) Fokkens WJ, Lund VJ, Mullol J, Bachert C, Alobid I, Baroody F, et al. EPOS 2012: European position paper on rhinosinusitis and nasal polyps 2012. A summary for otorhinolaryngologists. Rhinology 2012;50(1):1-12.

28) Hong CK, Kim YB, Hong JB, Lee KS. Sealing of cerebrospinal fluid leakage during conventional transsphenoidal surgery using a fibrincoated collagen fleece. J Clin Neurosci 2015;22(4):696-9.

29) Blomstedt GC. Infections in neurosurgery: A retrospective study of 1143 patients and 1517 operations. Acta Neurochir (Wien) 1985;78(34):81-90.

30) Mathias T, Levy J, Fatakia A, McCoul ED. Contemporary approach to the diagnosis and management of cerebrospinal fluid rhinorrhea. Ochsner J 2016;16(2):136-42.

31) Kim DS, Park CS, Kim YI, Kim IS, Sung JH, Yang SH. Clinical outcomes of transsphenoidal approach for pituitary adenomas following rhinosinusitis surgery. J Korean Skull Base Soc 2019;14(1): 28-33.

32) Smith TR, Hulou MM, Huang KT, Nery B, de Moura SM, Cote DJ, et al. Complications after transsphenoidal surgery for patients with Cushing's disease and silent corticotroph adenomas. Neurosurg Focus 2015;38(2):E12. 